\title{
Quality evaluation of fresh-cut 'Pérola' pineapple stored in controlled atmosphere
}

\author{
Avaliação da qualidade do abacaxi 'Pérola' minimamente
} processado, armazenado sob atmosfera controlada

\author{
Lucimara Rogéria ANTONIOLLI ${ }^{1}$, Benedito Carlos BENEDETTI ${ }^{2 *}$, \\ José Maria Monteiro SIGRIST ${ }^{3}$, Neliane Ferraz de Arruda SILVEIRA ${ }^{3}$
}

\begin{abstract}
The purpose of this research was to determine the best gas mixture in controlled atmosphere conditions to store fresh-cut 'Pérola' pineapple, particularly in relation to the maintenance of visual quality and reduction of microbial growth. After sanitation, fruit was manually peeled, sliced and dipped in $20 \mathrm{mg} . \mathrm{L}^{-1} \mathrm{NaOCl}$ solution for 30 seconds. Then, the excess liquid was drained and the slices were placed in sealed glass jars connected to a flowboard installed in a cold room $\left(5 \pm 1{ }^{\circ} \mathrm{C}\right)$. Desired gas mixtures were supplied continuously for 12 days from cylinders connected to the flowboard. Controlled atmospheres of 2:5, 2:10, 2:15, 5:5, 5:10, 5:15, 8:5, 8:10 and 8:15 $\left(\mathrm{O}_{2}: \mathrm{CO}_{2}\right.$, \%) and air were used. The product was evaluated for pulp color, total and fecal coliforms, mesophilic and psychrotrophic aerobic, mold and yeast counts. Total and fecal coliforms were not detected. The fresh-cut 'Pérola' pineapple was not very sensitive to storage in controlled atmosphere, considering that the slices had little browning and were free of contamination, that would affect the food safety at the end of the storage period.

Keywords: Ananas comosus; minimal processing; gas mixture; quality; microbial growth.
\end{abstract}

\section{Resumo}

Procurou-se determinar a composição gasosa ótima para o armazenamento do abacaxi 'Pérola' minimamente processado, particularmente com relação à melhoria da qualidade visual e à redução do crescimento microbiano. Frutos previamente sanitizados foram descascados e fatiados manualmente. As fatias foram imersas em solução de $\mathrm{NaOCl} 20$ mg.L $\mathrm{L}^{-1}$ durante 30 segundos. Após período de repouso, para drenagem do excesso de líquido, foram acondicionadas em frascos de vidro herméticos conectados a um fluxcentro instalado em câmara refrigerada a $5 \pm 1{ }^{\circ} \mathrm{C}$. As composições gasosas desejadas foram fornecidas continuamente, durante 12 dias, a partir de cilindros conectados ao fluxcentro. As combinações de $\mathrm{O}_{2}: \mathrm{CO}_{2}(\%)$, balanceadas com $\mathrm{N}_{2}$, foram as seguintes: 2:5, 2:10, 2:15, 5:5, 5:10, 5:15, 8:5, 8:10 e 8:15. O tratamento controle foi o ar atmosférico. Os parâmetros analisados foram: cor, coliformes a 35 e a $45^{\circ} \mathrm{C}$, microrganismos aeróbios mesófilos, psicrotrófilos, bolores e leveduras. Não foram detectados coliformes totais e fecais. A combinação $5: 15\left(\mathrm{O}_{2}: \mathrm{CO}_{2}, \%\right)$ reduziu ligeiramente $\mathrm{o}$ crescimento microbiano, entretanto o abacaxi 'Pérola' minimamente processado parece ser pouco sensível ao armazenamento sob atmosfera controlada, considerando-se que ao término do armazenamento as fatias apresentavam-se pouco escurecidas e livres de contaminação que comprometesse a segurança do alimento.

Palavras-chave: Ananas comosus; processamento mínimo; composição gasosa; qualidade; crescimento microbiano.

\section{Introduction}

Consumption of fresh-cut fruit and vegetables has been increasing because of their convenience and high quality. However, it is essential that these fresh-cut fruit and vegetables preserve the freshness and nutritional quality of the whole products, as well as being free of microbial contamination that would offer risks to the consumers ${ }^{7,11}$. Fresh-cut pineapple can be found in some shops, but its shelf-life is very limited (approximately 23 days) because of the quality loss represented, mainly, by pulp browning and the accumulation of liquid in the packaging.

Controlled atmosphere (CA) and low temperatures provide the maintenance of quality and shelf-life prolongation of fruit and vegetables. As every tropical fruit, the pineapple experiences chilling damage when stored at temperatures below $12{ }^{\circ} \mathrm{C}$, O'CONNOR-SHAW et al. ${ }^{14}$ did not observe symptoms of this disturbance in fresh-cut pineapple stored at $4{ }^{\circ} \mathrm{C}$. Oxygen

Recebido para publicação em 14/7/2006

Aceito para publicação em 18/7/2007 (001792)

Apoio Financeiro: FAPESP; PRODETAB/BANCO MUNDIAL

${ }^{1}$ Embrapa Uva e Vinho, CP 130, CEP 95700-000, Bento Gonçalves - RS, Brasil

Faculdade de Engenharia Agrícola - FEAGRI

Universidade Estadual de Campinas - UNICAMP, CP 6011, CEP 13083-875,

Campinas - SP, Brasil,

E-mail:benedeti@agr.unicamp.br,

Instituto de Tecnologia de Alimentos, CP 139, CEP 13073-001,

Campinas - SP, Brasil

* A quem a correspondência deve ser enviada levels below $1 \%$ and/or $\mathrm{CO}_{2}$ levels above $10 \%$ are needed to significantly suppress fungal growth ${ }^{10,20}$. According to FARBER ${ }^{6}$, the metabolic alterations caused by $\mathrm{CO}_{2}$ cause the cell stress, resulting in the reduction of microbial growth rates.

The storage of pineapples in $\mathrm{CA}$ of $3-5 \% \mathrm{O}_{2}+5-8 \% \mathrm{CO}_{2}$ provides the reduction of respiration rates and the prolongation of its shelf-life. The exposition of this fruit to $\mathrm{O}_{2}$ levels below $2 \%$ and $\mathrm{CO}_{2}$ levels above $10 \%$ seems to favor the development of off-flavors ${ }^{12}$. Relatively ampler limits of $\mathrm{CO}_{2}$ and $\mathrm{O}_{2}$ (1-20\% $\mathrm{CO}_{2}$ and $2-5 \% \mathrm{O}_{2}$ ) were established to preserve pineapples ${ }^{15}$. However, there is little available information concerningt the ideal conditions of CA to store fresh-cut fruit. It was reported that levels of $10 \% \mathrm{CO}_{2}$ cause the reduction in the deterioration of fresh-cut 'Champaka' pineapples, while $\mathrm{O}_{2}$ levels below $5 \%$ lead to the development of off-flavors from the fermentative metabolism ${ }^{9}$.

The low levels of $\mathrm{O}_{2}$ used when being stored at $5{ }^{\circ} \mathrm{C}$ of freshcut 'Champaka' pineapples caused retention of the yellow color, whereas high $\mathrm{CO}_{2}$ reduced brown discoloration ${ }^{13}$. According to these authors, storing fresh-cut pineapple in $2 \% \mathrm{O}_{2}+10 \% \mathrm{CO}_{2}$ extended post-cutting life for more than two weeks.

Using CA (air $+15 \% \mathrm{CO}_{2}$ ) reduced color changes in fresh-cut 'Cantaloupe' and 'Honeydew' melons ${ }^{16}$. In a similar 
way, lower alteration in pulp color of fresh-cut 'Jonagored' apples when they were stored in $\mathrm{CA}$ of $2 \% \mathrm{O}_{2}+12 \% \mathrm{CO}_{2}{ }^{18}$ was observed.

The purpose of this research was to determine the best gas mixture, in CA conditions, to store fresh-cut 'Pérola' pineapple, particularly in relation to maintaining the visual quality and reduction of microbial growth.

\section{Materials and methods}

Pineapple fruits (Ananas comosus (L.) Merril, cv. Pérola) were harvested from a commercial grower in Miranorte - TO (Center-West region of Brazil), pre-selected and transported to the "Instituto de Tecnologia de Alimentos" (ITAL), Campinas - SP. Then, the fruit was selected in relation to the size and the shell color (fruit with the fruitlets center yellow), washed with water and neutral detergent and disinfected in 200 mg. $\mathrm{L}^{-1}$ sodium hypochlorite $(\mathrm{NaOCl})$ solution for 2 minutes. Fruit was placed in washed and disinfected (200 mg.L. $\mathrm{L}^{-1} \mathrm{NaOCl}$ solution) plastic boxes and kept at $20^{\circ} \mathrm{C}$ conditions for approximately 20 hours. After that, the fruit was manually peeled and transversely sliced (approximately $10 \mathrm{~mm}$ thick) and the cores were removed $^{1}$

The slices were dipped in a solution of $\mathrm{NaOCl}\left(20 \mathrm{mg} . \mathrm{L}^{-1}\right)$ for 30 seconds, which was kept at $10^{\circ} \mathrm{C}$. The excess liquid was drained for 2 minutes and the slices were placed in previously disinfected, air-tight glass jars $(3.6 \mathrm{~L})$ which were connected to a flowboard ${ }^{3,4}$, installed in a cold room at $5 \pm 1{ }^{\circ} \mathrm{C}$. The flowboard system ensured the continuous flow of humid and cold air for 12 days. Gas mixtures were supplied from cylinders connected to the flowboard. Nine controlled atmospheres of 2:5, 2:10, 2:15, 5:5, 5:10, 5:15, 8:5, 8:10 and 8:15 $\left(\mathrm{O}_{2}: \mathrm{CO}_{2}, \%\right)$ and air were used.

Gas mixture flow was based on the respiration rate of fresh-cut pineapple. Studies carried out with fresh-cut 'Pérola' pineapple showed that respiration rates of slices and chunks were approximately $3.0 \mathrm{mg} \mathrm{CO} \cdot \mathrm{kg}^{-1} \cdot \mathrm{h}^{-1}$ between the $2^{\text {nd }}$ and $12^{\text {th }}$ days of storage at $5 \pm 1{ }^{\circ} \mathrm{C}^{1}$.

All the processing was carried out in refrigerated conditions, with temperatures between 12 and $15{ }^{\circ} \mathrm{C}$. The equipment and utensils were disinfected with $200 \mathrm{mg} . \mathrm{L}^{-1} \mathrm{NaOCl}$ solution to prevent crossed contamination. Disposable gloves, masks and headwear were used with the same intention.

Fresh-cut pineapple was evaluated on day 0, after sanitation, and at 2, 5, 8 and 12 days. Three replications were used for each treatment. Each replication consisted of a glass jar with eight slices (approximately $0.550 \mathrm{~kg}$ ). The pulp color was measured with a Minolta Chromameter (Model CR-300, Minolta) in the CIE $\mathrm{L}^{*} \mathrm{a}^{*} \mathrm{~b}^{*}$ mode. The $\mathrm{L}^{*}$ and $\mathrm{a}^{*}$ parameters, recommended for apples ${ }^{2}$, were used to evaluate fresh-cut pineapple browning.

The presence of total coliforms $\left(35^{\circ} \mathrm{C}\right)$ and fecal coliforms $\left(45^{\circ} \mathrm{C}\right)$ in the fresh-cut pineapple was evaluated on day 0 . Mesophilic and psychrotrophic aerobic counts were made at 0,5 and 12 days. Mold and yeast counts were made at 0, 2, 5, 8 and 12 days. The initial evaluation was made after washing with water and neutral detergent. Analyses were carried out according to the methodology described in the Compendium of Methods for the Microbiological Examination of Foods, "APHA"5.

The experiment was arranged in completely randomized design, with three replications, where interaction between gas mixture and the storage period were studied. Data were analyzed by analysis of variance (ANOVA) and the separation of means was by Tukey's multiple range test at $\mathrm{p} \leq 0.05$. Mesophilic and psychrotrophic aerobic, mold and yeast population were transformed into $\log (\mathrm{x})$ and expressed in log CFU.g ${ }^{-1}$.

\section{Results and discussion}

The pulp color analysis based on the $\mathrm{L}^{*}$ value showed that no statistical difference was found between the fruit stored in $\mathrm{CA}$ and the control (Figure 1a). There was a slight reduction in this parameter with the storage period for all treatments, attributed to the gradual loss of the samples lightness. The values varied between 75.78 and 71.80 during the period of cold storage, resulting in a reduction of $5.25 \%$ (Figure 1c). Similar results were found by GIL et al. ${ }^{8}$, who did not observe statistical differences in the $\mathrm{L}^{*}$ value of the pulp color of 'Fuji' apple slices when stored for 3 days in $0.25 \% \mathrm{O}_{2}$ or in air. However, slices stored in $0 \% \mathrm{O}_{2}$ were significantly lighter in color than those stored in either air or $0.25 \% \mathrm{O}_{2}$. In another way, the different conditions of $\mathrm{CA}$ (air, $2 \% \mathrm{O}_{2}$, air $+12 \% \mathrm{CO}_{2}$ and $2 \% \mathrm{O}_{2}+12 \% \mathrm{CO}_{2}$ ) did not interfere in the rapid browning of peaches after slicing ${ }^{19}$.

The low $\mathrm{O}_{2}$ concentrations ( $2 \%$ ) with $10 \% \mathrm{CO}_{2}$ or $15 \% \mathrm{CO}_{2}$ resulted in $\mathrm{a}^{*}$ values of the pulp color statistically lower than the control. However, no significant difference was found between both gas mixtures (Figure 1b). There was a gradual increase in the $\mathrm{a}^{*}$ value from the $2^{\text {nd }}$ day of storage in CA (Figure 1d). An increase of $22 \%$ in this parameter of color was observed, with values between -3.04 , on day 0 and -2.37 on the $12^{\text {th }}$ day of storage. However, this alteration was not visually noticeable. The contribution of red to the color is characterized when the $a^{*}$ values become positive, and this fact was not observed until the end of the storage period.

Total and fecal coliforms were not detected in fresh-cut samples collected on day 0 (after disinfection), which suggest an absence of the microorganisms in the fruit and indicate that processing was carried out under appropriate sanitary conditions.

A relatively low population of mesophilic aerobic, psychrotrophic and mold and yeast (3.65, 1.78 and 3.95 log CFU.g ${ }^{-1}$, respectively) was observed in the initial evaluation of the fruit, made after washing with neutral detergent and water.

Statistical interaction between the factors (gas mixture and storage period) for mesophilic aerobic and mold and yeast population was observed, but not for psychrotrophic aerobic microorganisms. Regardless of the storage period, the psychrotrophic aerobic population found in the slices stored in CA conditions varied between 2.79 and 4.18 log CFU.g ${ }^{-1}$, without differing from the population observed in the samples stored in air (3.74 log CFU.g $\left.{ }^{-1}\right)$. Although not differing from the control, the highest population (4.18 $\log$ CFU.g ${ }^{-1}$ ) was ob- 
(a)

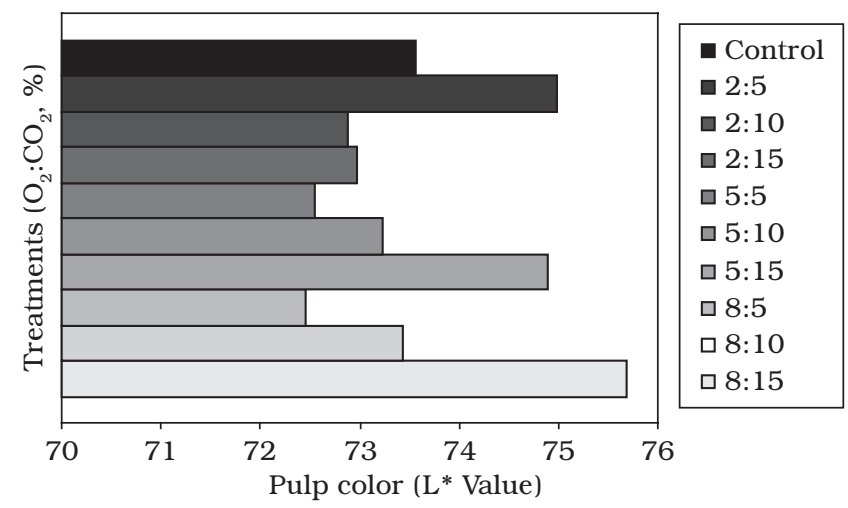

$\mid \mathrm{LSD}=2.53$

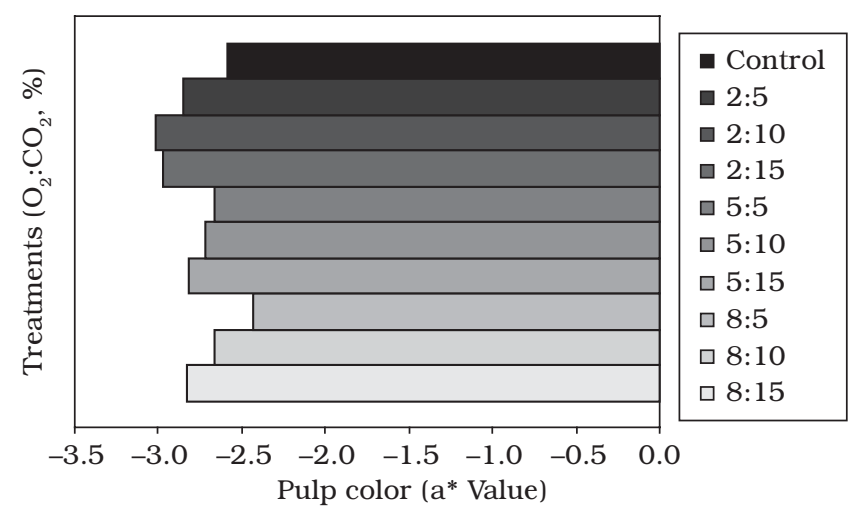

$\mid \mathrm{LSD}=0.34$

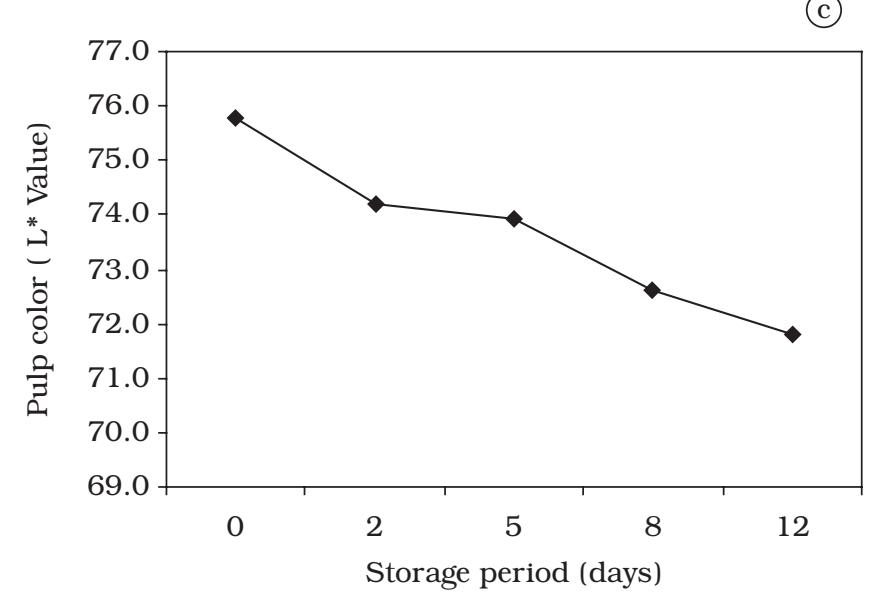

$\mid \mathrm{LSD}=1.54$

(d)

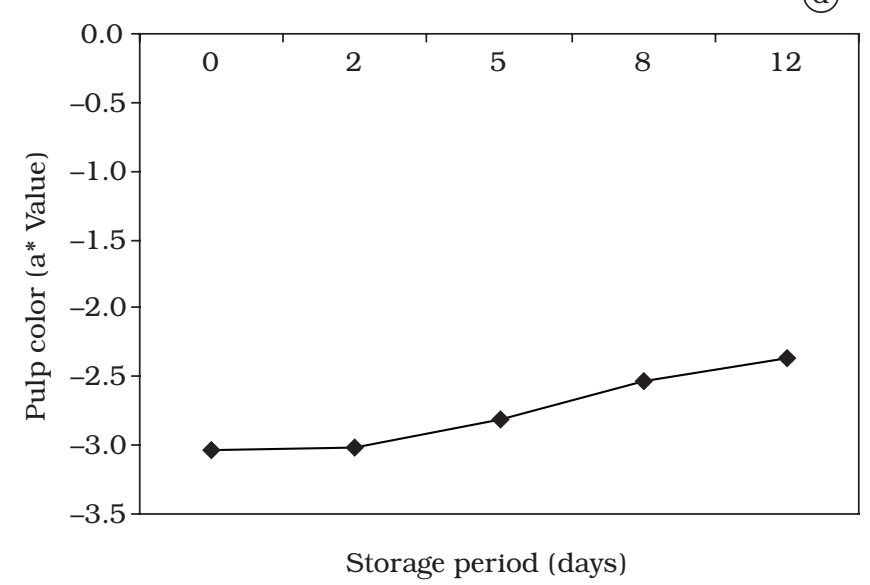

$\mid \mathrm{LSD}=0.20$

Figure 1. Pulp color of fresh-cut 'Pérola' pineapple stored in different conditions of controlled atmosphere for 12 days at $5 \pm 1{ }^{\circ} \mathrm{C}\left(\mathrm{a}\right.$ and $\mathrm{c}$ : $\mathrm{L}^{*}$ value; $b$ and $d: a^{*}$ value). Vertical bars show the least significant differences at 0.05 level.

served in the samples stored in $\mathrm{CA}$ of $8 \% \mathrm{O}_{2}+5 \% \mathrm{CO}_{2}$. Five treatments differed from this one and three of them presented $15 \% \mathrm{CO}_{2}$ in their gas mixture (Figure 2a). Considering the population observed in the initial evaluation ( $\left.1.78 \log \mathrm{CFU} . \mathrm{g}^{-1}\right)$, an increase of $2.0 \log$ cycles was observed on day 0 , when the population reached $3.47 \mathrm{log}$ CFU.g ${ }^{-1}$. Although maintaining itself in $10^{3}$ CFU.g ${ }^{-1}$, a reduction in this count was observed on the $5^{\text {th }}$ day, followed by an increase that raised the population to levels observed on day 0 (3.44 log CFU.g $\left.{ }^{-1}\right)$.

The minimal processing of pineapple did not provide an increase in the mesophilic aerobic population, considering the counts in the initial evaluation and on day 0 (3.65 and 3.63 $\log$ CFU.g ${ }^{-1}$, respectively). There were no significant differences between the control and the population of slices stored in CA until the $5^{\text {th }}$ day of refrigerated storage. In this evaluation, the highest population (4.71 $\log$ CFU.g ${ }^{-1}$ ) was observed in the samples stored in $\mathrm{CA}$ of $8 \% \mathrm{O}_{2}+5 \% \mathrm{CO}_{2}$. On the $12^{\text {th }}$ day, the mesophilic aerobic population in the slices stored in the CA conditions of $5 \% \mathrm{O}_{2}+15 \% \mathrm{CO}_{2}$ and $8 \% \mathrm{O}_{2}+15 \% \mathrm{CO}_{2}$ were statistically lower than in the control, without differing between them. The CA of $5 \% \mathrm{O}_{2}+15 \% \mathrm{CO}_{2}$ promoted the lowest mesophilic aerobic count (2.83 log CFU.g ${ }^{-1}$ ) and reduction in the population by $2.0 \mathrm{log}$ cycles when compared to the control (4.33 log CFU.g ${ }^{-1}$ ). The population of 3.09 log CFU.g ${ }^{-1}$ was observed in slices stored in $\mathrm{CA}$ of $8 \% \mathrm{O}_{2}+15 \% \mathrm{CO}_{2}$. Although these gas mixtures provided low counts on the $12^{\text {th }}$ day, the mesophilic aerobic population presented little variation, with values oscillating between $10^{2}$ and $10^{4} \mathrm{CFU}_{\text {.g }}{ }^{-1}$ (Figure 3 ).

A slight reduction in the mold and yeast population was observed on day 0 (3.53 log CFU.g ${ }^{-1}$ ) when compared to the initial population ( $3.95 \log$ CFU. $\left.g^{-1}\right)$. Up to the $5^{\text {th }}$ day of storage, there were no significant differences between the control and the population of fresh-cut fruit stored in CA. This behavior was also observed in the mesophilic aerobic population. Although not differing from the control, the highest populations were observed in the slices stored in $\mathrm{CA}$ of $8 \% \mathrm{O}_{2}+5 \% \mathrm{CO}_{2}$ on the $2^{\text {nd }}$ and $5^{\text {th }}$ days. Statistically lower populations than the control were observed in the slices stored in the CA conditions of 2:10, 
(a)

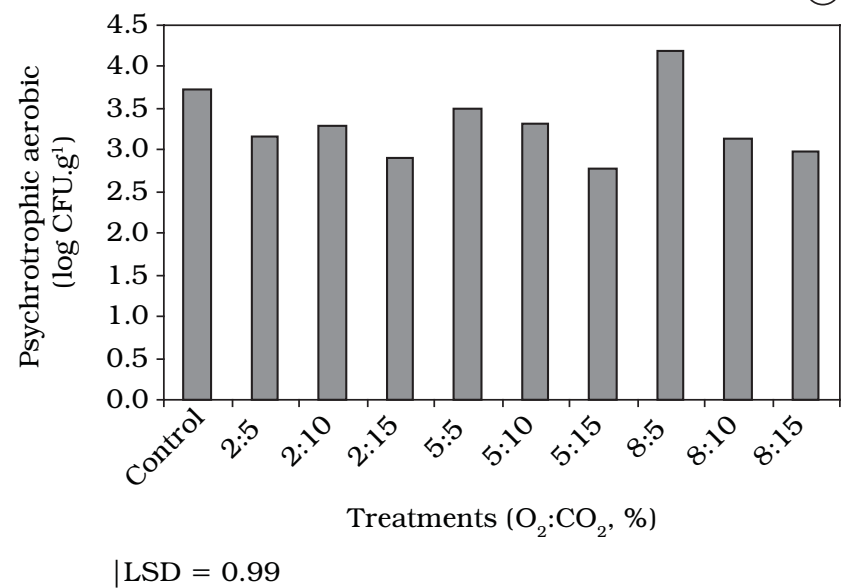

(b)

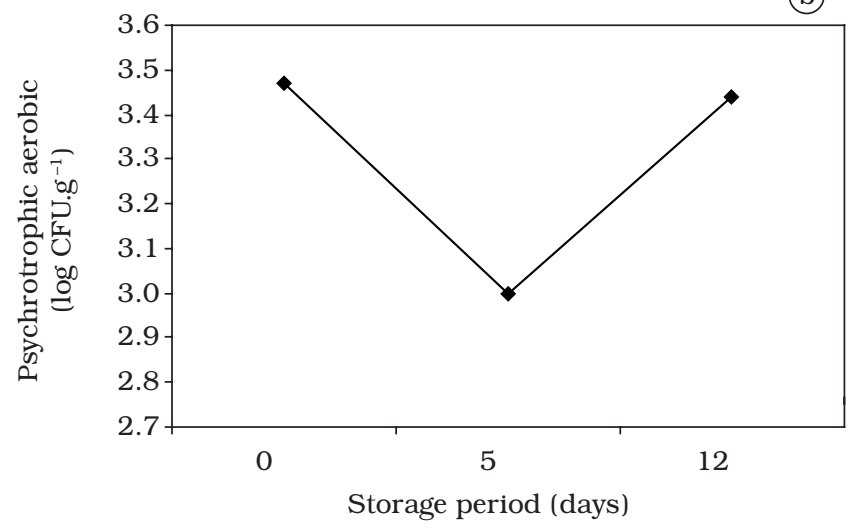

LSD $=0.39$

Figure 2. Psychrotrophic aerobic (log CFU.g $\left.{ }^{-1}\right)$ in fresh-cut 'Pérola' pineapple stored in different conditions of controlled atmosphere a); and for 12 days at $5 \pm 1{ }^{\circ} \mathrm{C} \mathrm{b}$ ). Vertical bars show the least significant differences at 0.05 level.

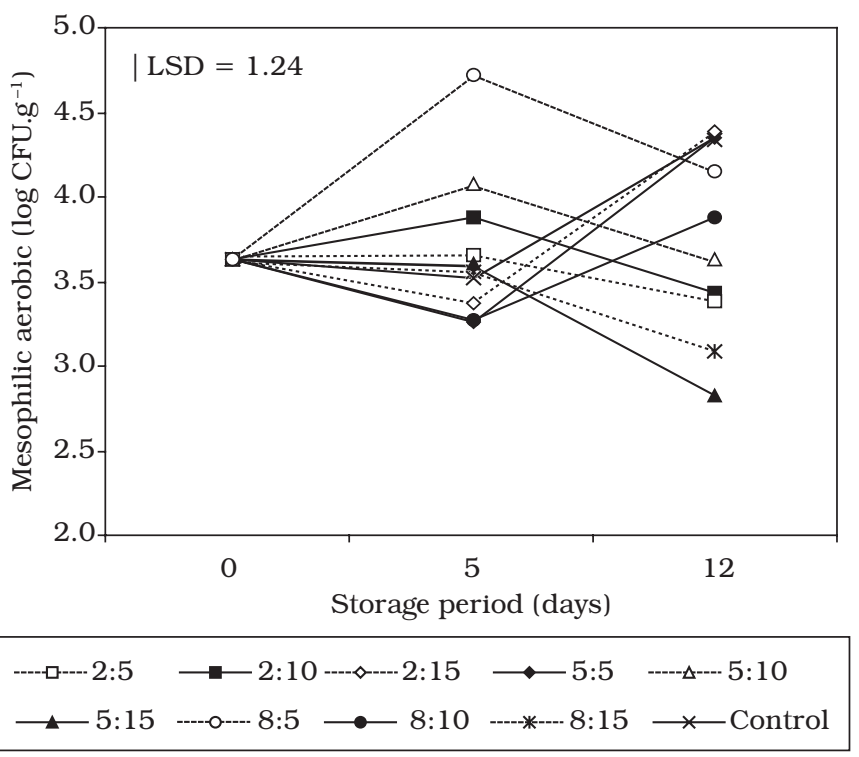

Figure 3. Mesophilic aerobic ( $\left.\log \mathrm{CFU} . \mathrm{g}^{-1}\right)$ in fresh-cut 'Pérola' pineapple stored in different conditions of controlled atmosphere for 12 days at $5 \pm 1{ }^{\circ} \mathrm{C}$. Vertical bar shows the least significant differences at 0.05 level.
2:5, 8:15 and 5:15 $\left(\mathrm{O}_{2}: \mathrm{CO}_{2}, \%\right)$ on the $8^{\text {th }}$ day. At this time of evaluation, the lowest mold and yeast count (3.16 log CFU.g ${ }^{-1}$ ) was observed in the fresh-cut pineapple stored in CA of $5 \%$ $\mathrm{O}_{2}+15 \% \mathrm{CO}_{2}$. However, this population did not differ from that found in the slices stored in CA of 2:10, 2:5 and 8:15 $\left(\mathrm{O}_{2}\right.$ : $\left.\mathrm{CO}_{2}, \%\right)$. On the $12^{\text {th }}$ day, the $\mathrm{CA}$ of $5 \% \mathrm{O}_{2}+15 \% \mathrm{CO}_{2}$ provided lower mold and yeast count (3.46 log CFU.g ${ }^{-1}$ ) and a reduction in the population by $2.0 \mathrm{log}$ cycles when compared to the control (5.22 log CFU. $g^{-1}$ ). However, the population found in this gas mixture did not differ from that observed in the CA conditions of 8:15, 2:15, 2:5, 8:10 and 5:10 $\left(\mathrm{O}_{2}: \mathrm{CO}_{2}, \%\right)$. Regardless of the fresh-cut pineapple stored in air and CA of $8 \% \mathrm{O}_{2}+5 \%$ $\mathrm{CO}_{2}$ which presented the highest mold and yeast populations at the end of the storage period (5.22 and 6.02 log CFU.g ${ }^{-1}$, respectively), it was observed that these populations oscillated between $10^{3}$ and $10^{4}$ CFU.g ${ }^{-1}$ throughout the first 8 days of refrigerated storage (Figure 4).
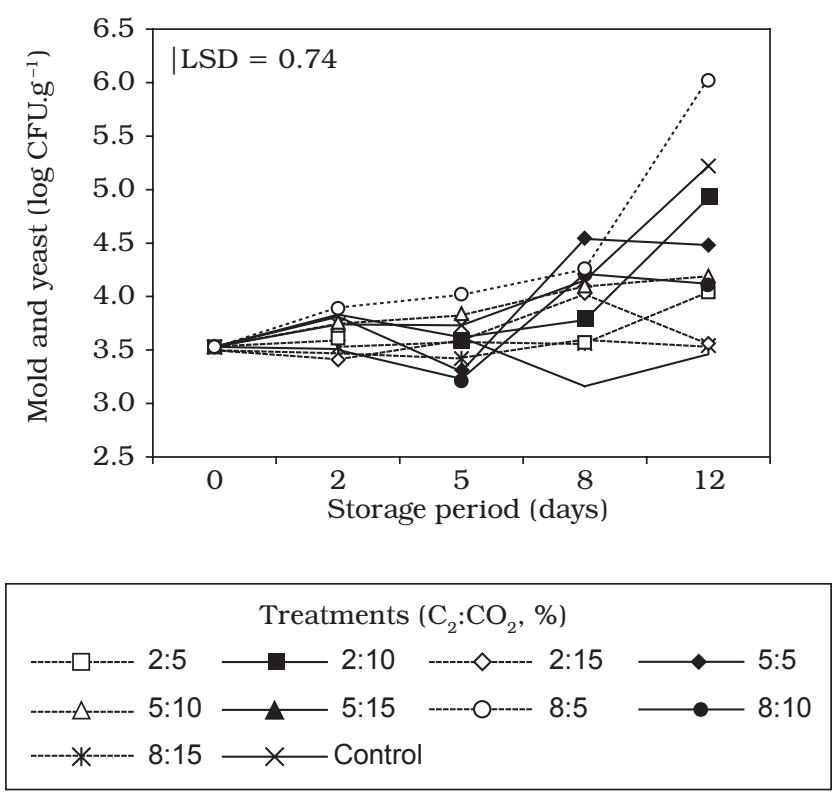

Figure 4. Mold and yeast ( $\log$ CFU.g $\left.{ }^{-1}\right)$ in fresh-cut 'Pérola' pineapple stored in different conditions of controlled atmosphere during 12 days at $5 \pm 1{ }^{\circ} \mathrm{C}$. Vertical bar shows the least significant differences at 0.05 level.

QI et al. ${ }^{17}$ observed lower mesophilic aerobic and mold and yeast population in fresh-cut 'Honeydew' melon, when the cubes were stored in $\mathrm{CA}$ of $2 \% \mathrm{O}_{2}+10 \% \mathrm{CO}_{2}$ and $5{ }^{\circ} \mathrm{C}$. However, the mold and yeast population observed in this gas mixture differed from the control only on the $10^{\text {th }}$ day, and similar behavior was not observed in the mesophilic aerobic population. According to O'CONNOR-SHAW et al. ${ }^{14}$, the microbial growth did not appear to contribute to spoilage in diced pineapple for 11 days of storage at $4{ }^{\circ} \mathrm{C}$.

In spite of the gas mixture of $5 \% \mathrm{O}_{2}+15 \% \mathrm{CO}_{2}$ having slightly reduced the microbial growth, fresh-cut 'Pérola' pineapple seems to be not very sensitive to storage in CA considering that the slices had little browning and were free of contamination that would affect the food safety at the end of the storage 
period. Perhaps, maintaining the microbial population in relatively low levels was a result of refrigerated storage, low initial contamination of the intact product and sanitary conditions, and not an effect of the CA storage.

\section{Conclusions}

Fresh cut 'Pérola' pineapple is not very sensitive to storage in controlled atmosphere. The controlled atmosphere of $5 \% \mathrm{O}_{2}+15 \% \mathrm{CO}_{2}$ slightly reduces the microbial growth in fresh-cut 'Pérola' pineapple.

\section{Acknowledgements}

This research received financial support from the Fundação de Amparo à Pesquisa do Estado de São Paulo (FAPESP). The authors would like to thank White Martins Praxair Inc. for supplying the gas mixtures and Débora Belo Alves for her technical contribution to this research.

\section{References}

1. ANTONIOLLI, L. R. Processamento mínimo de abacaxi 'Pérola'. 2004. 166 p. Tese (Doutorado em Engenharia Agrícola) Universidade Estadual de Campinas, Campinas, 2004. Disponível em: libdigi.unicamp.br/document/?code $=$ vtls000318352

2. ARTÉS, F.; CASTAÑER, M.; GIL, M. I. Revisión: el pardeamiento enzimático en frutas y hortalizas mínimamente procesadas. Food Science and Technology International, London, v. 4, n. 6, p. 377-389, 1998

3. CALBO, A. G. Adaptação de um fluxcentro para estudos de trocas gasosas e um método de aferição de capilares. Pesquisa Agropecuária Brasileira, Brasília, v. 24, n. 6, p. 733-739, 1989.

4. CLAYPOOL, L. L.; KEEFER, R. M. A colorimetric method for $\mathrm{CO}_{2}$ determination. Proceedings of the American Society for Horticultural Science, Alexandria, v. 40, p. 177-186, 1942.

5. DOWNES, F. P.; ITO, K. Compendium of methods for the microbiological examination of foods. Washington: American Public Health Association - APHA, 2001. 676 p.

6. FARBER, J. M. Microbiological aspects of modified-atmosphere packaging technology - a review. Journal of Food Protection, Des Moines, v. 54, n. 1, p. 58-70, 1991.

7. GARRETT, E. H. Fresh-cut Produce: Tracks and Trends. In: LAMIKANRA, O. Fresh-cut fruits and vegetables: science, technology, and market. Boca Raton, Florida: CRC Press LLC, 2002, 467 p.
8. GIL, M. I.; GORNY, J. R.; KADER, A. A. Responses of 'Fuji' apple slices to ascorbic acid treatments and low-oxygen atmospheres. HortScience, Alexandria, v. 33, n. 2, p. 305-309, 1998.

9. GORNY, J. R. Packaging design for fresh-cut produce. Alexandria: International Fresh-Cut Produce Association, 2003. $122 \mathrm{p}$.

10. KADER, A. A. Biochemical and physiological basis for effects of controlled and modified atmospheres on fruits and vegetables. Food Technology, Chicago, v. 40, n. 5, p. 99-104, 1986.

11. KADER, A. A. Quality parameters of fresh-cut fruit and vegetable products. In: LAMIKANRA, O. Fresh-cut fruits and vegetables: science, technology, and market. Boca Raton, Florida: CRC Press LLC, 2002, 467 p.

12. KADER, A. A. Pineapple: recommendations for maintaining postharvest quality. Disponível em: <http://rics.ucdavis.edu/ postharvest2/Produce/ProduceFacts/Fruit/pineapple.shtml > . Acesso em: 22 jul. 2003.

13. MARRERO, A.; KADER, A. A. Factors affecting the post-cutting life and quality of minimally processed pineapple. Acta Horticulturae, Wageningen, v. 2, n. 553, p. 705-706, 2001.

14. O'CONNOR-SHAW, R. E. et al. Shelf life of minimally processed honeydew, kiwifruit, papaya, pineapple and cantaloupe. Journal of Food Science, Chicago, v. 59, n. 6, p. 1202-1206, 1215 p., 1994.

15. O'CONNOR-SHAW, R. E. et al. Changes in sensory quality of sterile cantaloupe dice stored in controlled atmospheres. Journal of Food Science, Chicago, v. 61, n. 4, p. 847-851, 1996.

16. PORTELA, S. I.; CANTWELL, M. I. Quality changes of minimally processed honeydew melons stored in air or controlled atmosphere. Postharvest Biology and Technology, Amsterdam, v. 14, n. 3, p. 351-357, 1998.

17. QI, L.; WU, T.; WATADA, A. E. Quality changes of fresh-cut honeydew melons during controlled atmosphere storage. Journal of Food Quality, Trumbull, v. 22, n. 5, p. 513-521, 1999.

18. ROCHA, A. M. C. N.; MORAIS, A. M. M. B. Effects of controlled atmosphere on quality of minimally processed apple (cv. Jonagored). Journal of Food Processing and Preservation, Trumbull, v. 24, n. 6, p. 435-451, 2000.

19. WRIGHT, K. P; KADER, A. A. Effect of controlled-atmosphere on the quality and carotenoid content of sliced persimmons and peaches. Postharvest Biology and Technology, Amsterdam, v. 10, n. 1, p. 89-97, 1997.

20. ZAGORY, D. Controlled and modified atmospheres. I - General aspects of film technology and selection. In: ANNUAL WORKSHOP FRESH-CUT PRODUCTS: MAINTAINING QUALITY AND SAFETY, 5, 1999, Davis. Proceedings... Davis: University of California, 1998. Section 7a, p. 1-3. 